Ciência eNatura, v. 37 Part 2 jun. 2015, p. 23-34

ISSN impressa: 0100-8307 ISSN on-line: 2179-460X

\title{
ciênciaenatura
}

\section{Shahname Firdausi and Transformational Management with Attitude Comparison Ulrich Transformation Pattern}

\author{
Shirin Samsami ${ }^{1}$ and Mahdokht Purkhaleghi Chatrudi ${ }^{2}$ \\ 1Student of Persian language and literature, Mashhad Firdausi University, International \\ branch, faculty member of Tabas Islamic Azad University \\ ${ }^{2}$ Professor of Mashhad Firdausi University
}

\begin{abstract}
Investigating valuable works of literature by scientists of different fields and publication of various books associated with literature and other sciences emphasize on the important issue that literature does not belong just to emotion and taste. Rather it includes a wide range of sensory experiences based on concrete facts. One of the new sciences whose principles can be used in investigation of literary texts is management. Abolghasem Firdausi's Shahname which provides unlimited time and place has presented various events. In these various events, numerous people with different human actions and interactions play their roles; therefore, Shahname is an appropriate research target for those researchers who are interested in interdisciplinary research such as literature and management, particularly management of human resources. In this regard, the researcher in the present study aims to make relation between one of modern management concepts transformational management- with management strategies of Shahname and through descriptive-analytic method introduce the country's local management principles and also indicate that transformation in Shahname follows Ulrich transformation pattern. Leadership, establishment of shared needs, shared attitudes, commitment, transformation management, change supervision, and change stability can be mentioned as similar points emphasized by Firdausi and Ulrich regarding change.
\end{abstract}

Keywords: management, transformation, Firdausi 


\section{Introduction}

Human resources management appeared in 1980s and evolved as a new era in human power management. Today, it is a consensus that human resources management cannot replace staff management, but rather looks at staff management processes from a different perspective. Moreover, its basic philosophies are significantly different from traditional concepts of staff management. However, some special approaches of staff management and relationships can be described under the title of human resources management processes, since they are along with basic philosophy of human resources management (Armstrong, 1993: 33).

Since human resources management was raised as a professional field big companies and different governmental offices established different departments and institutions under this name. Efforts by University scholars and communication with executive managers through publication of useful articles introduced the importance and techniques of human resources management and made this expertise known as a profession which led to development of activities related to human resources management (Mirsepasi, 1389:7).

Along with fast development of technology, human capital has been considered as an important organizational asset. Human capital includes a set of skills, knowledge, and general characteristics of individuals in organizations and can indicate the capacity of performing today's works and the potential for tomorrow's affairs (Tonke Nejad, 1388: 51).

Today, change and transformation can be increasingly evident in all aspects of human life and therefore, organizations are inevitably faced with innovation and coordination with changes and transformations in different areas of life. However, it is obvious that planning, designing, and management are needed in order to make effective and constructive changes in organizations. Transformation management has been also called transmission management which includes basic processes of planning and organizing as well as applying change from the stage of disturbing the status quo to full realization of complete preparation for work in future.

Given that change is an inevitable principle of existence, if people and organizations suffer mechanical and repetitive order, they will be doom to destruction. Management science has come to the fact that human capital is especially important in order to establish change, since theorists have found that human beings are main operators of each organization and mold it to life and also facilitate realization of organizational objectives (Jarfi, 1387: 62).

Accordingly, proper infrastructure to create and foster change is regarded an inevitable organizational necessity. An important factor that provides the grounds for development and growth of change is innovation in organizational environment which can lead to expected results through effective leadership.

The present study aims to present the history of local management based on literary masterpieces. Since, the birthplace of scientific management and academic knowledge in America, a big number of management studies has been done this country and in the context of American companies: therefore, many management theories stem in American culture and affected by national factors of this country. Use of these theories by managers in other countries and teaching them in management schools is only done based on the presupposition of management universalism, while its complete acceptance is doubted by some management scholars (Laurence, 1994: pp543-561), (Chaw, 1992: pp53-67), (Attia, 1992: pp123-130), (Adler, 1992: 52-65), and (Hickson, 1995: p7).

In the absence of consensus about management universalism, applying management theories in other countries except their birthplace will need more studies in order to test and confirm their applicability. These kinds of local studies and researches are the basis of local management in every country. Authors believe that studies which investigate the nature of Iranian staff 
work and the results as well as achievements obtained by successful managers fostered in local context are fundamental research elements which can be used by students in this field.

It should be noted that literature does not only belong to emotion and feeling. A literary work is not just a personal experience; rather it is a broad scope of sensory experiences which refer to objective facts. Persian literature is a treasure of valuable raw materials including Iranians' intellectual works during ages. In this regard, the greatest Persian literary work, Shahname, has been investigated through the following questions:

How much has Firdausi paid attention to management strategies?

How does Firdausi consider transformation management?

Research hypotheses include:

1. Given that Shahname is Iranians' politicalsocial life story, different management issues are raised in it.

2. Firdausi believes in the principle of change and transformation and applies proper management reactions according to individual and social needs.

3. Patterns introduced by Firdausi can be applied in today's modern society.

\section{Discussion}

Transformation has been defined in dictionary as "change in form, structure, or nature of something". Organizational transformation strategy is accompanied with planning and guarantees organizational forehanded response to new needs while organization can continue its activities effectively in a dynamic environment (Seyed Javadin, 1387: 267). In another definition it is said that: transformation is creating everything that is different from the past and accordingly, innovation is adoption of ideas which are new to the organization (AghaiFishani, 1377:26). According to Hansen, change includes transformation which is evident in behaviors, structures, policies, purposes, or outputs of some organizational departments (Hansen, 1370:330). However, given the closeness and similarity between concepts of innovation and change in many scientific texts and resources, these two words are usually used interchangeably.

On the other hand, variety is one of characteristics of human resources management (Armstrong, 1389: 23). In other words, human resources experts seek innovation in order to obtain organizational effectiveness provided that they are not involved in impression management; it means innovation which is only for attracting others' attention. This is what Drucker (1909-2005) calls constant concern of human resources managers (ibid: 117).

Shahname kings, regardless of projection provide the grounds for transformation without seeking to attract others' attention. Not only they don't affect their pears' governance practices, but they also help them in the best way. Respect to a group's good traditions is considered as honor to their identity and their intellectual followers. This kind of attitude will reduce oppositions and bias. Conflict between groups who support the previous government and those who support the present one will disappear and consequently, public will be far from these tensions which will in turn lead to a calm society ready to accept innovative changes.

Shapur asks his son Hormoz not to forget his advice as he himself has listened to Ardeshir's exhortations.

Learn all my advice one by one

As once I listened to Ardeshir's exhortations (Firdausi, 1391: 250/6)

Nersi calls his son Urmazd at the time of death and advises him:

Keep the world according to kinds' regulations

As you learned from your pure Lord (ibid: 282/6)

Firdausi with all his commitment - which leads to his inflexibility in many cases - does not ignore transformation principle or innovation when he knows it leads to progress. 
Marriage is one of taboos raised in Shahname. The first marriage takes place at the time of Feridun. "Jandal" searches all territory of Feridun to find girls counterpart of Iranian princes.

He searched across the land of Iran

He sought and said and heard

In every country when a lord

Had a daughter at home

Secretly he found all their private matters

Listened to all about their name and fame (ibid: 93/1)

However, at the time of Zal, society needs a new attitude. Sam is worried about sustainable basic change and is doubtful about Zal's choice:

Two substances like water and fire

Cannot be gathered together in a place

Obviously, at the day of decision

Feridun and Zahak will fight together (ibid: 209/1

Mehrab, Rudabeh's father is the same. He is so angry that he has not followed the ancestors:

When I had a daughter

He asked me to kill her at the time

I didn't do it and I didn't follow my fathers' way

Now I have such a unique property

When a son does not follow his father's way

He is not regarded as his ancestors' son (ibid: 216/1)

This view says that organizational identity is realized in its history and mixture of traditions, values, and customs as well as what organizational staff consider important and also familiar behaviors patterns to which they are accustomed and with which they feel convenient (Tusi, 1372:202).

However, the problem is solved through organizational development. Fast changes which are accompanied by social transformations and lead to major changes in life style, needs, and individual values require replacement of traditional patterns with flexible organizational processes (Borumand, 1385:5). Organizational development is a reaction to the intention of changing values and organizational structure so that the organization can adapt itself with rapid transformations (ibid: 12 ).

The story of Zal's marriage from top management's point of view is supported by Manuchehr, and in lower levels by Sam, Sindokht, and eventually Mehrab. There are a lot of challenges in implementing this decision. The final conclusion is that they should be adapted to new conditions in order to keep the government.

His management is sometimes high performance; it absorbs human resources carefully and trains them; it also designs jobs carefully and eventually evaluates performance. Sometimes his management is high commitment; employees have selfcontrol and self-regulation; flexibility is a part of planning; and discrimination and bias is forgotten. Sometimes high-participation management is considered important; kings behave subordinates like people whose benefits are respectable; governors aim to establish atmosphere where subordinates and superordinate have continuous interaction and express their expectations without fear.

Although some scholars believe that organizational culture may prevent organizations to cope with their environment (Borumand, 1385:58), Firdausi has sought variety in this regard and has proved through role-, success-, power-, and support-oriented culture that organizational culture will be effective in coping with environment. Readers can refer to "contingency management" in order to get information on organizational cultures raised in Shahname (Purkhaleghi Chatrudi, Samsami, 1392: 191-213).

Moreover, innovation is not forgotten in executive strategies; sometimes in wars the issue of ambush is raised (Firdausi: 643/8). Other times, disguised people penetrate into enemy (ibid: 487/7) and sometimes they show superiority of Iranian armies by digging ditches (ibid: 424/8). 


\section{Transformation pattern}

Ulrich (1998), one of human resources management scholars in temporary era, has proposed a theory regarding "transformation pattern" where he has investigated the key elements of successful change (Armstrong, 1389:119). Matching this pattern with leadership system in Shahname shows significant similarities some of which are presented here:

\subsection{Leadership}

The first influencing factor from Ulrich point of view is leadership while managers know themselves and their team members innovative. Requirement of promoting change by leaders will lead to higher value of staff, while it will also increase leadership hardships and complexities (Fathi, 1392: 69).

In other words, transformational leadership is prerequisite of success in every planning. This organizational element encourages others to try and achieve important goals instead of considering short-term benefits (Seyed Javadin, 1387:133). In Firdausi's Shahname all changes start with managers. Every optimal use of resources and human as well as financial assets should be toward community excellence and realization of governmental objectives.

According to Emami Shushtari, if we have a look at Iran's history from perspective of life ethics, we will find that the word "king" is not associated with cruelty; rather kings advance human culture (Emami Shushtari, 1350:3).

Kiumars kingdom which is the first kingdom in Shahname is accompanied by planning for establishment of change in people's life style so that even their lodging and clothing is not ignored by the king:

He was careful about all the life matters

People had both new clothes and food in his kingdom

Firdausi: 22/1

When primary needs are dealt with, society changes its direction toward industrialization.
Hushang is a successful leader; he explores iron and makes metal tools:

He found some gems at first try

And then separated iron and stone by fire (ibid: 29/1)

This shows that the importance of keeping pace with rapid manifestations of change keeps leaders in continuous anxiety on how to cope with different aspects of change (Fathi, 1392:70).

These changes are completely directed while priority and delay of affairs can indicate this orientation. Provision of food and lodging means attention to human's primary needs and then attention to morals and spreading theism is an evidence of this claim. Agriculture, animal husbandry, and leather industry are all the consequences of these major changes. This structure is proposed by Abraham Maslow as a famous management theory. These changes are obviously supported by the king and trainings performed in order to establish change indicate governmental support system.

Maybe there are no seminars or meetings in Shahname in today's concept, but the presence of general and technical training cannot be denied.

The first formal education at the time of Tahmureth is provided by demons:

They taught the lord how to write

Knowledge made his heart bright as the sun

Not only one, but almost thirty

From Roman, to Arabic, and Persian

And also Sogdian, Chinese, and Pahlavi,

All the writings being heard of around (Firdausi: 37/1).

Even kings taught their subordinates:

He taught them how to spin and twist

How to weave the warp and woof

When woven, how to wash and sew,

They learned from him whatever to do (ibid: 42/1) 
Technical training can be performed among classes that are allowed to be educated. In addition to physical training (such as wicket, hunting, and martial arts), kings undergo thought education as well. Siavash is nursed by Rostam:

Riding, archery, and lasso

Bridle, pedal, the way to do what

How to sit in an assembly, how to drink

The same eagle with the game of query

Justice, injustice, throne, and crown

Speaking at the time of war, guiding troops

Taught him all the arts equally

Endured great suffering to conclude

Siavash was trained so that in the world

No one could excel him from superiors (ibid: 207-208/2)

At the time of Hushang, the king himself acts like his people and does not hesitate to follow up the affairs:

Everyone tried to get his own daily bread

Got his own sufferings and knew his own work

(ibid: 30/1)

He suffered, spread, ate, and saved for others

He went and people remembered him with his good name

(Firdausi: 31/1)

\subsection{Creating common needs}

Creating common needs is another key factor of change. The reason of change should be clear. People should know why change is necessary; in other words, they should be completely aware of the reasons and importance of change. Objectives are defined for people. They know keeping criminals away from the city means security and kumars was the first person who did this work (ibid: 22). Hushang made saw and ax from iron in order to develop agriculture and animal husbandry (ibid: 29-31). In sum, initial lectures by kings at the time of coronation can be considered as evidence for all these changes.

In the course of Zal and Sudabe marriage, Sindokht, Zal, and Sudabe have a very scientific and deep attitude. While Mehrab fears the primary results of this change, Sudabe seeks to get privileges from this attitudinal change:

Sudabe was surprised by what he said

She praised $\mathrm{Zal}$ as her couple

He is great and the champion of the world

His name, his thought, and his pure spirit

He has all the arts and he is unique

The one who lacks no art except little

(ibid: 215/1)

Bringing astronomers together once by Zal and another time by Manuchehr in order to evaluate and justify this change is further evidence; in other words, if $\mathrm{Zal}$ is going to get married with a girl from Zahak generation and changes occur in Iranian society, it should have a valuable reason:

From these two great famous artists

Some should come and show his arts

He should dominate the world with his power

His kingdom prospered all over the world

He will put down all bad people

So that there will be no devil on the earth

Iranians have their hope in him

He invites heroes over and gives them hope

(ibid: 209/1)

This marriage has also good outcomes for Manuchehr and consequently for people, since he will be a champion with no peers:

$\mathrm{He}$ is at the service of the city

All Iranians will seek refuge in him

(ibid: 247/1)

\subsection{Shared vision}


This factor shows the importance of what happens after change for governors and people. At the time of Tahmureth, teaching weaving and development of textile industry indicates the attention that the leader has toward primary needs and his perception of the importance of change as well as staff awareness of change outcomes; in other words, they know that how behaviors will be different after change happens. Insisting on teaching Persian writing is observed from a wise king who wants to open people's eyes to a new world. Certainly it can be said that both the king knows that managing literate people is more difficult and the people know that they are not supposed to live as before (ibid: 37/1).

Astronomers have predicted a good ending for Zal and Rudabe marriage; however, it's not going to happen without planning and foresight. If there is going to be a change in people's taboos, it should worth it; therefore, Zal has to have a big test (Purkhaleghi Chatrudi, 1378:84). His intelligence and understanding should be tested and his martial arts including bow, archery, and wrestling need to be evaluated. When they come to the conclusion that:

No generation has experienced such a power

His excellence is beyond any human

(ibid: 255/1)

This marriage is confirmed.

\subsection{Commitment}

When change occurred this question is raised that if there is any commitment regarding the change or not and who should be involved in the change. The answer to this question can be investigated in "Jamshid" kingdom, since his society experiences change from the first day to the last minutes of his charismatic life.

Hushang made primary tools from iron and used them in agriculture. This innovation was then developed. Jamshid knew that new requirements need new changes and therefore he put making instruments of war and proper clothes according to modern conditions of the society in his plans (ibid:41).
The sequence of changes is amazing. Primary needs such as food and clothing are regarded at the first step. After dealing with these needs, social security and then people's health as well as development of medicine are among Jamshid's plans. The next need is social belonging which is achieved by social ranking. Everyone is assigned a rank and a special responsibility which should be known and followed. Keepers of fire went to mountains:

They were there to pray the Lord

And shiver from the fright of God

(ibid: 42/1)

Armies kept the order of the country:

By them kingdom remains in power

They are those known to manhood (ibid)

farmers were granted a social class:

They plant and care and reap

They are not beholden for their daily bread (ibid)

And craftsmen obtained a separate identity:

All those who had the same profession

Had their minds busy on the affairs of profession

(ibid: 43/1)

Management scholars always emphasize that a transformational manager should go beyond ordinary problems (Seyed Javadin, 1387: 133).

People are not the only committed factors of change. At the Time of Tahmureth, writing is taught by demons:

The great lord gave them permission and security

To show their abilities hidden from the eyes

They taught the lord how to write

Knowledge made his heart bright as the sun

(ibid: 37/1)

And at the time of Jamshid, construction of buildings is done by their help and participation: 
He ordered the foul demons

To mix the soil and water

When the clay was ready as they knew

Bricks were made by special molds

Demons made walls by stone and stucco

They were familiar with the art of geometry

(Firdausi: 43/1)

In order to address the needs and change people's lives, leaders don't ignore even animals. Teaching hunting and using animals and poultry can be evidence in this regard (ibid: 35-36/1).

Involving employees in management decisions, inviting them and creating a proper environment to ask their ideas and innovative suggestions, encouraging them for creative activities, respectful behavior with staff, supporting them and giving them enough freedom to do activities in more effective ways will all lead to creativity and innovation in the organization and will make people more committed (Jarfi, 1387:65 and Alvani, 1385:241).

Attention to the principle of consultation and participation is present in Shahname in the sense of sharing in the process of decision making with other organizational members in order to achieve organizational objectives and also in the sense of the degree an individual affects decisions related to his job or the degree of staff involvement in organizational decision making (Mahdizade, 1392: 107); this element completes commitment.

Firduasi is completely aware that people who participate in change and are involved in its processes will also accept it easily. Participation means people accept new roles in new conditions or react properly which can be considered a key point in participatory management.

Presence of consultants from different classes of noblesse, officials, heroes and warriors, as well as astronomers indicate that Shahname governors on one hand, have identified committed people and on the other hand have the ability to establish responsibility patterns for realization of transformation.
I'll make decisions with those who are resourceful,

With counsel I will win over my passion.

I will ask my minister in the affairs,

This way, I'll start new affairs (ibid: 406/6)

The most beautiful representation of this strategy in Shahname is evident at formation of military councils. Before war, kings formed councils including commanders and grandees in order to decide based on existing conditions. Anushiravan formed one of these councils when he heard about invasion of the Roman Empire to the boundaries of Iran:

When the king read the letter

He got upset by the play of the time

All men and priests were summoned

To speak on the letter together

He was consulting with them all the day

While the army champions gave advice

Finally the king came to his decision

To move his army and fight with Gheisar

(ibid: 126/7)

Military council is a representation of democratic management where the manager allows his employees to participate in decision making. With such an attitude there will be consensus on all decisions. This kind of management is useful when complex decisions are supposed to be made (Freeman, $1375,417)$. This management principle has a high frequency in Shahname and it can be investigated in other studies in detail.

\subsection{Leading the change}

Each change should be directed by the organizational leader. One of the issues that concern the manager at the time of change is how to stimulate labor. In the first steps of change, it seems that employees don't have motivation and are not interested in tasks assigned to them.

Among evidence of attention to this principle in Shahname transformations, one can refer to recruitment, performance evaluation, 
attention to reward and educational system. Certainly, "reward" is an important tool for creating motivation toward goal (Moorhead, 1358:231) and consequently it is an important factor in optimal use of human resources. Firdausi believes in this principle' Rostam receives a significant reward after Mazandaran war.

Tahamtan came while he had a helmet on

He sat next to the king's throne

The lord of the land of Iran praised him

And granted him a robe with all his praise

Again the lord gave the great hero

Government of Sistan for another time

(Firdausi: 63 \& 64/2)

According to Firdausi's view even an enemy who has done a valuable service should not be excluded from kindness of the king; therefore, Mazandaran government is granted to Oulad by mediation of Rostam. Rostam knows his victory due to this champion's guidance and therefore:

When he listened to the speech of his servant

The wise king crossed his hand together

He called the grandees of Mazandaran

And spoke to them on different matters

He assigned him the government of the land

And then departed to Pars from there (ibid: $62 / 2$ )

Granting praises and rewards for good works can be further evidence that this attitude is a representation of a successful leadership. These leaders try to stimulate important woks and promote commitment and enthusiasm (Iran Nejad Parizi, 1385:230).

\subsection{Supervision on change}

According to Beckhard (1928-1999), change is a planned effort which takes place across the organization and under supervision of organization's top management in order to increase efficiency and effectiveness (Beckhard, 1996:9).

This factor is not neglected by Shahname kings. Maybe there is not an evaluation tool in its modern sense in order to measure the amount of change success in Shahname, but considering control principle in Shahname shows that there is a kind of supervision on development of change.

However, this issue has a special position in Shahname in different ways. Sometimes, this control is performed through special factors and mechanisms - court of nobles. The manager receives positive and negative reports from reliable middlemen and then reports his views directly or through active factors in supervision system (Taghavi Damghani, 1380:97). The high frequency word "detectives" in Shahname refers to people who are sent to different areas in order to inform king about the situation of his territories. These people are the first group for keeping the control of the community.

Sometimes governors involve in some issues directly; Bahram Gur is a king who enters into his people's houses unknown in order to find out about their conditions. Afterward, the result of his observations is evident in giving the wealth of Jewish Ibrahim to "Lanbak" (ibid: 424/6).

Physical presence is not only associated with the country's inner issues; it is also true about external matters. Bahram Gur dresses in messengers' clothes and risks his life to give a letter to Chengel, Indian king.

I'll see his army alone

His kingship and his throne

I'll go to him like messengers

I won't tell anyone from Iran (ibid: 541/7)

\subsection{Recording change}

The last factor of change success is recording change from Ulrich point of view. Shahname kings know exactly where to start change and they have short-term as well as long-term plans to concentrate on proposed changes. This claim is provable at first of Shahname at the time of Hushang and Jamshid's kingdom. The sequence of change is proportionate to needs and these plans are performed in three periods during 50 years of Jamshid's kingdom.

First he went toward military tools 
He gave the army the chance to show themselves

In these fifty years of his kingdom

He suffered a lot to strengthen his territories

Afterward he thought about the clothes

Supposed to be worn in the battles

When it was finished he started a new job

He was happy by fortune and everyone satisfied with him

He summoned professionals from all areas

During fifty years he did whatever he could (ibid:/1)

Here, changes are recorded and accordingly social structure of the community is designed; however, he spends fifty years of his life to obtain this goal:

For everyone he chose a position

Which deserved and showed the path

So that everyone's position

Is seen and known more or less (ibid: 43/1)

He is aware of this unique effect:

The art flourished from me in the world

No one has been as famous as me in kingdom

I adorned the world in the best way I could

The world is like this, what else do I want? (ibid)

In Hushang government a change is recorded in order to start another transformation which is related to discovery of iron:

When he understood he started forging

He made saw and ax this way

When it was done he thought about water

He made rivers from the seas

He developed pastures with the water

Then scattered seeds, planted and harvested (ibid:/1)

This fortitude continues until the outcomes of change are evident in the society and his name is remembered with honor among his people:
He suffered, spread, ate, and gave to others

He went while people remember his good name

He suffered a lot those days

With so many thoughts and numerous ideas (ibid)

In the section related to supervision, we talked about exact control in Shahname. Using information collected by agents and ontime planning for it is another strong point in Firdausi's management regarding recording of change:

Everyone who is poor in the city

With no chance of happiness in his life

Should be sent to us with their names

To help them to get their dreams

Everyone who is in debt but has no money

Or those who have jobs without income or honor

Pay their debts from our worldly treasures

Record their names in the courts all

(ibid: 538/7)

\section{Conclusion}

According to evidence, it can be concluded that Firdausi's Shahname is a complete example of transformational management. In Shahname, all changes start with leaders. Shahname governors do not try to attract others' attention and just want to provide grounds for transformation with the help of experiences of previous governors and based on respect to ancestors which will bring security and calmness to the society; this calmness is necessary for establishment of innovation.

Change is ranked based on community's discretion and is directed wisely. Shahname governors support change firmly if they know it will lead to progress. This claim came to realization in Jamshid's kingdom. Haman tries to explain the reasons of change for beneficiaries - employers and public- and confirm it according to the principle of shared 
needs. Zal and Rudabe marriage and emphasis on the outcomes of this marriage result from this attitude.

Afterward, they try to involve all society members in this change so that everyone from every social class can accept a special responsibility; therefore, the principle of participation is not forgotten. They know well that if transformation is not directed properly, it will be useless. Governors' wise attitude toward recruitment, performance evaluation, and attention to reward and education system can emphasize the presence of this principle in Shahname.

Directing change in Shahname is accompanied by supervision which is not neglected by Shahname governors. . Maybe there is not an evaluation tool in its modern sense, but considering control principle in Shahname shows that there is a kind of supervision on development of change. The last factor in a successful change is recording changes which can be seen in Firdausi's work. Using information collected by agents and ontime planning for it is another strong point in Firdausi's management regarding recording of change.

\section{References}

Adler, N; Bartholomew, S (1992). Managing globally competent people, Academy of Management Executive, Vol.6, No.3, pp52-56

Aghai Fishani, Teimur (1377). Creativity and innovation in humans and organizations, Tehran, Terme Publishing, 1st edition. (In Persian)

Alvani, Seyed Mohammad (1385). General management, Tehran, Nei Publishing, 23rd edition (In Persian)

Armstrong, Michael (1389). Strategic management of human resources, translated by Mohammad Arabi and Omid Mahdieh, Tehran, office of cultural studies, 1st edition

Atiyyah, H (1992). Designing management training programs in a developing country: a case study, Management Education and Development, Vol.23, No.2, pp123-130
Beckhard, Richard (1967). The confrontation meeting, Harvard, Business Review, 45 (March, April)

Borumand, Zahra (1385). Organizational improvement and recovery, Tehran, Heiat Publishing, 3rd edition. (In Persian)

Chowl, H (1992). Chinese managerial work, Journal of general management, Vol.17, No.4, pp53-67

Cohen, M.D. \& Sproull, L.S (1991). Editor's introduction. Organization science, 2(1)

Emami Shushtari, Mohammad Ali (1351). Kings' history in Iran's kingdom, Tehran, Ministry of Art and Culture Publishing, 1st edition.

Fathi, Azam; Ahanchian, Mohammad Reza; and Karashki, Hussein (1392). BM style and its relationship with organizational effectiveness, journal of transformational management, 5th year, No.9, pp69-88 (In Persian)

Firdausi, Abolghasem (1391). Shahname, by Jalal Khaleghi Motlagh, Tehran, Islamic Great Encyclopedia Center, 4rd edition (In Persian)

Freeman, Edward, James Stoner (1375). Management, translated by Ali Parsaian and Seyed Mohammad Arabi, vol1, Tehran, Bazarghani Publishing, 1st edition

Hanson, Mark (1370). Educational management and Organizational behavior, translated by Mohammad Ali Naeli, Ahvaz, Shahid Chamran University

Hickson, D.J; Pugh, D.S (1995). Management worldwide: the impact of societal culture on organizations around the globe, penguin, pp7

Iran Nejad Parizi, Mehdi (1385) Principles and basics of management in contemporary world, 1st edition. (In Persian)

Jarfi, Saeed et al (1378). Investigating the effects of participatory decision making on employees' job satisfaction (case study: agricultural bank of Khuzestan), management sciences journal, No.30, pp61-76. (In Persian)

Khafi, Marzieh (1391). Critical and descriptive research paper of Firdausi and Shahname from 1371 to 1380, doctorate thesis, advisor: Mohammad Jafar Yahaghi, Mashhad Firdausi University. 
Lawrence, P (1994). In another country or the realization of managerial learning, Management Learning, Vol.25, No.4, pp543561

Mahdizade, Mehran; Dorostkar Ahmadi, Nahid; and Ramazanian, Mohammad (1392). Designing conceptual model of participatory decision making as a strategy for improvement of attitudes, emotions, and staff performance in work life, journal of transformational management, 5th year, No.9, pp104-133 (In Persian)

Mirsepasi, Naser (1389). Strategic management of human resources and work relations, Tehran, Mir Publishing (in Persian)

Moorhead, Griffin (1358). Organizational behavior, translated by Seyed Mohammad Alvani and Gholam Reza Memarzade, Tehran, Morvarid Publishing, 11th edition (in Persian)

Purkhaleghi Chatrudi, Mah Dokht (1387). Shahname tree, symbolic and cultural values of tree in Firdausi's Shahname, Mashhad, Astane Ghods Publishing, 2nd edition. (In Persian)

Saadat, Esfandiar (1390). Human resources management, Tehran, Samt Publishing, 11th edition (In Persian)

Seyed Javadin, Seyed Reza (1387). Management of human resources and staff affairs, Tehran, Negahe Danesh Publishing, 5th edition (In Persian)

Seyed Yazdi, Zahra (1387). Critical and descriptive research paper of Firdausi and Shahname based on Iraj Afshar articles index up to 5th book in 1370, doctorate thesis, advisor: Mohammad Jafar Yahaghi, Mashhad Firdausi University. (In Persian)

Taghavi Damghani, Reza (1380). An attitude toward Islamic management, Tehran, Islamic Propagation Organization, 3rd edition. (in Persian)

Tunke Nejad, Mandani, and Davari, Ali (1388). Development of human resources with sociological approach toward organization. Research journal of human resources management, Imam Hussein University, first year, number3, pp51-80 (in Persian)
Tusi, Mohammad Ali (1372). Organizational culture, Tehran, center of public management education, 1st edition 